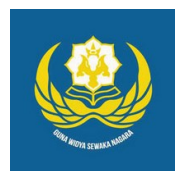

Jurnal Analogi Hukum

Journal Homepage: https://ejournal.warmadewa.ac.id/index.php/analogihukum

\title{
Ketidakhadiran Pihak Termohon Dalam Pemeriksaan Cerai Talak (Studi Kasus Nomor: ooog/Pdt.G/2018/PA.Bdg)
}

\author{
I Putu Gede Anom Purnacandrama*, A.A Sagung Laksmi Dewi dan Luh Putu Suryani
}

Universitas Warmadewa, Denpasar-Bali, Indonesia

*purnacandrama@gmail.com

\author{
How To Cite: \\ Purnacandrama, I, P, G, A., Dewi, A, A, S, L., Suryani, L, P. (2020). Ketidakhadiran Pihak Termohon Dalam Pemeriksaan Cerai Talak (Studi \\ Kasus Nomor: 0009/Pdt.G/2018/PA.Bdg). Jurnal Analogi Hukum, 2 (2). 197-202. Doi: http://dx.doi.org/10.22225/.2.1.1603.1-6
}

\begin{abstract}
Research in this thesis is motivated by a case that occurred in the community, lately there are many divorces in the community, the verdict verstek in the case of divorce can be met in the case of a trial where one of the parties are not present in the proceeding for any reason or no legitimate reason. In section 125 HIR paragraph $1 \mathrm{HIR}$, the verdict of verstek as the ruling of a religious court in a civil lawsuit is one of the decisions entered into the final award. The problems is 1 . How is legal force of verstek in the examination of divorced cases, 2 . How does the judges' decision to impose verstek verdict on divorced matters. The method used in making this journal is the normative method. By the law of Indonesia civil proceedings regarding the verdict of this verstek is governed in article $125 \mathrm{HIR}$ or $149 \mathrm{RBg}$. The absence of either party or the absence of the defendant party on the day of the prescribed trial is one of the conditions to be able to in verstek ruling by majelis of judges Badung religious courts that led the trial in a civil lawsuit. The method by which researchers use is the normative method which is a study based on secondary data and libraries. With this verstek ruling that the legal force remains the tribunal granting the applicant a request in the trial. As is the case that entered into the badung religious court with the register number 0009/PDT.G/2018/PA.Bdg.
\end{abstract}

Keywords: Divorce, verstek, verdict, court verdict.

\begin{abstract}
Abstrak-Penelitian dalam jurnal ini dilatar belakangi adanya kasus yang terjadi di masyarakat, akhir-akhir ini banyak terjadi perceraian di kalangan masyarakat, putusan verstek dalam perkara cerai talak dapat kita jumpai dalam perkara di pengadilan dimana salah satu pihak tidak hadir dalam persidangan dengan alasan maupun tanpa alasan yang sah. Pada pasal 125 ayat (1) HIR. Putusan verstek sebagai putusan hakim pengadilan agama dalam perkara perdata adalah salah satu putusan masuk dalam tahap putusan akhir. Rumusan masalahnya 1) bagaimana kekuatan hukum verstek dalam pemeriksaan cerai talak, 2) bagaimana keputusan hakim tentang penjatuhan putusan verstek terhadap perkara cerai talak. Metode yang digunakan dalam pembuatan jurnal ini adalah metode normative. Dalam hukum acara perdata Indonesia mengenai putusan verstek ini diatur dalam pasal $125 \mathrm{HIR} / 149 \mathrm{RBg}$. Ketidakhadiran salah satu pihak atau ketidakhadiran pihak tergugat pada hari sidang yang telah ditentukan adalah salah satu syarat untuk bisa dijatuhkannya putusan verstek oleh majelis hakim pengadilan agama badung yang memimpin persidangan dalam perkara perdata. Metode yang digunakan peneliti adalah metode normative yang merupakan penelitian yang berdasarkan bahan hukum sekunder dari perpustakaan. Dengan putusan verstek ini yang berkekuatan hukum tetap majelis hakim mengabulkan permintaan pihak pemohon dalam persidangan seperti halnya perkara yang masuk di Pengadilan Agama Badung dengan nomoister 0009/Pdt.G/2018/PA.Bdg.
\end{abstract}

Kata Kunci: Perceraian, Putusan Verstek, Putusan Pengadilan.

\section{Pendahuluan}

Indonesia merupakan Negara hukum yang sangat kuat dan di dasari oleh Pancasila dan berpedoman pada Undang-Undang Dasar Negara Republik Indonesia tahun 1945, entah itu hukum positif, hukum adat dan hukum lainnya yang ada di indonesia. Indonesia juga dikenal banyak suku dan adatnya yang berbedabeda, namun terkadang di Indonesia terdapat banyak sekali masalah hukum yang menyangkut tentang adat maupun yang menyangkut tentang hal yang diluar adat seperti halnya perebutan tanah warisan, tanah wilayah 
desa adat, bahkan juga ketidakharmonisan rumah tangga atau keluarga yang berujung dengan perceraian. Di Indonesia terdapat hukum positif yaitu hukum yang dibuat oleh lembaga legeslatif ditunjukan terhadap masyarakat untuk menetapkan tindakan atau tidak melawan batas wajar berprilaku dan bertindak. Dimana hukum positif juga mengatur masalah dan kegiatan yang menyangkut hukum positif tersebut, karena indonesia sangat berpedoman pada hukum positif dimana hukum positif adalah dasar hukum disetiap hukum yang ada di Indonesia.

Hukum adat yang berlaku di Indonesia terutama dalam hal pernikahan itu sangat kuat adatnya, tidak sewenang-wenang melakukan pernikahan dan hukum adat pun tetap berpedoman pada hukum positif yang ada di Indonesia karena pada umumnya pernikahan dilakukan di masjid atau dipengadilan setempat karena adat di indonesia sangat kuat dan kekal maka pernikahan pun jika dilakukan dan di dasari oleh hukum adat akan dilakukan di setiap daerah yang ada di Indonesia dan dengan adat yang berbeda-beda tetapi tetap tidak mengesampingkan hukum positif dan prosedur pernikahan dengan hukum positif. Seperti halnya sebuah perkawinan pasti disaksikan oleh masyarakat sebagai salah satu bukti bahwa pernikahan itu sah, karena ada saksi yang menyaksikannya, bukan hanya saksi perkawinan juga pasti dicatat dalam catatan sipil setempat dan diterbitkannya akta perkawinan sesuai prosedur dari hukum positif yang menggunakan pemerintahan untuk mengesahkan akta perkawinan tersebut.

Pada hakekatnya perkawinan didasari oleh rasa antara laki-laki dan perempuan yang ingin menyatukan perasaan mereka berdua untuk melanjutkan rasa mereka ke jenjang yang lebih serius untuk membuktikan bahwa perasaan mereka sudah cocok dan patut di bawa ke pelaminan untuk membentuk sebuah keluarga yang kekal.

Pada prinsipnya perkawinan atau nikah adalah suatu akad untuk menghalalkan hubungan serta membatasi hak dan kewajiban setiap pasangan yang menikah dimana prinsip perkawinan yaitu untuk membentuk suatu keluarga yang tentram penuh kasih dan tak saling mengkhinanati maka dari itu pernikahan wajib dilakukan oleh semua umat manusia disatu sisi juga untuk meneruskan keturunan mereka untuk mewarisi harta benda yang dimiliki pasangan tersebut, tolong menolong antara laki-laki dan perempuan yang antara keduanya bukan muhrim, dimana arti tolong menolong adalah bermasyarakat yaitu terjun langsung ke masyarakat mengikuti aturanaturan yang ada dalam masyarakat seperti halnya rapat warga untuk suatu kepentingan yang ada dilingkungan tersebut. Apabila ditinjau dari segi hukum tampak jelas bahwa pernikahan adalah suatu akad suci dan luhur antara laki-laki dan perempuan yang menjadi sahnya status sebagai suami istri dan di halalkannya hubungan seksual dengan tujuan mencapai keluarga sakinah, penuh kasih sayang dan kebajikan serta saling menyantuni antara keduanya. Perkawinan menurut Hukum Islam adalah Pernikahan, yaitu akad yang sangat kuat atau miitsaaqongholiidhan untuk mentaati perintah Allah dan melaksanakannya merupakan ibadah.

Suatu akad perkawinan menurut Hukum Islam ada yang sah dan ada yang tidak sah. Akad perkawinan dikatakan sah, apabila akad tersebut dilaksanakan dengan syarat-syarat dan rukun-rukun yang lengkap, sesuai dengan ketentuan Agama. Sebaliknya, akad perkawinan dikatakan tidak sah bila tidak dilaksanakan dengan syarat-syarat dan rukun yang lengkap sesuai dengan ketentuan Agama. Sementara dalam pandangan ulama suatu perkawinan telah dianggap sah apabila telah terpenuhi baik dalam syarat maupun rukun perkawinan (Prodjohamidjojo, 2002).

Tujuan dari perkawinan yaitu untuk membentuk sebuah rumah tangga atau membentuk satu keluarga yang kekal, damai, dan sejahtera dimana untuk meneruskan keturunan dan juga untuk mencegah terjadinya perzinahan karena melakukan perzinahan akan mendapatkan dosa dan dibawa kejalur hukum untuk mencari jalan keluarnya karena melakukan zina sangat besar pengaruhnya untuk sebuah keluarga karena sudah tidak ada kata main-main jika suatu hubungan sudah sampai ke jenjang pernikahan. Dasar hukum dari perkawinan yang sah dan tercatat dalam undang-undang adalah Undang-Undang Republik Indonesia Nomor 1 Tahun 1974 tentang perkawinan dimana isi Undang-Undang tersebut berbunyi:

\section{Bab I Pasal 1 yang berbunyi :}

perkawinan ialah ikatan lahir batin antara seorang pria dengan seorang wanita sebagai suami istri untuk membentuk sebuah keluarga yang bahagia dan kekal berdasarkan ketuhanan yang maha esa.

\section{Pasal 2 yang berbunyi :}

Perkawinan adalah sah, apabila dilakukan menurut hukum masing-masing agamanya dan 
kepercayaannya itu

Tiap-tiap perkawinan dicatat menurut peraturan perundang-undangan yang berlaku.

Karena pernikahan sudah diatur dalam undang-undang yang jelas maka prosedur perkawinan pun harus sesuai dengan undangundang yang berlaku dimana perkawinan harus berdasarkan Ketuhanan yang maha esa dan dilakukan secara adat para pihak masingmasing, dengan restu orang tua untuk melancarkan proses pernikahan, para saksi yaitu warga sekitar untuk menyaksikan proses akad nikah dengan sah menurut undang-undang mauoun menurut hukum. Dimana proses pernikahan perlu ada saksi untuk mensyahkan sebuah pernikahan maka dari itu sangat diperlukannya warga sekitar atau sanak saudara untuk menyaksikan proses pernikahan tersebut.

Di setiap kehidupan tak selamanya sesuai dengan apa yang kita inginkan, terkadang kita pasti selalu dihadapkan oleh beberapa masalah seperti masalah keluarga yang cukup serius bukan hanya pertengkaran antara suami dan istri, bisa terjadinya KDRT, dan yang paling akhir dari semua itu adalah perceraian. Perceraian yang dapat dijelaskan disini yaitu putusnya hubungan antara suami dan istri yang disebabkan oleh masalah dalam rumah tangga yang mungkin masalah tersebut sudah tidak bisa dibicarakan baik-baik yang pada akhirnya berujung ke perceraian. Perceraian dalam arti luas yaitu, merupakan kata yang terdiri dari kata cerai yang berarti pisah, sehingga secara bahasa berarti putusnya hubungan suami istri, talak, hidup perpisahan antara suami dan istri semasih keduanya bernafas dan masih hidup.

Proses perceraian yang penulis bahas adalah cerai talak yang dimana prosesnya tersebut dibawa ke Pengadilan Agama Badung dengan nomor register 0009/Pdt.G/2018/ PA.Bdg. Dimana sebab terjadinya cerai talak tersebut karena rumah tangga yang bersangkutan ada unsur seorang istri sering menuduh suami hingga suami merasa jengkel. Perkara yang dibawa pihak pemohon atau seorang suami ke pengadilan adalah ingin mentalak pihak termohon dengan talak satu, pada saat pemanggilan pihak termohon oleh panitera pengganti tidak hadir dalam sidang pertama dimana sidang itu selanjutnya ditunda dan akan dillanjutkan pada hari sidang berikutnya.

Pada Penelitian sebelumnya (Malik, 2012), mengungkapkan ada beberapa faktor yang melatarbelakangi pemohon tidak hadir dalam ikrar talak antara lain: Adanya pembebanan atau kewajiban untuk membayar sejumlah uang yang harus dia bayar, meliputi: nafkah masa lampau, mut'ah, iddah dan nafkah anak, ketidak tahuan adanya pemanggilan karena pergi jauh, tidak tahu keberadaannya, Pemohon beranggapan dengan adanya putusan ijin ikrar talak dari Pengadilan Agama maka sudah selesai berperkara dan sudah cerai, faktor alam meliputi : rukun lagi dengan istri, meninggal dunia. Sedangkan untuk memperlancar proses perceraian (Putri, Bachtiar, \& Dasrol, 2016) mengungkapkan sebaiknya para pihak diwajibkan hadir pada sidang mediasi dan tidak boleh diwakili oleh kuasa hukumnya. Hal ini mengingat pelaksanaan mediasi menurut Perma adalah wajib dengan konsekuensi batalnya putusan jika tanpa melalui prosedur mediasi.

Berdasarkan apa yang telah penulis jelaskan di dalam latar belakang tersebut, maka penulis dapat menarik permasalahan yaitu:

Bagaimanakah kekuatan hukum verstek dalam pemeriksaan cerai talak?

Bagaimanakah keputusan hakim tentang penjatuhan putusan verstek dalam pemeriksaan cerai talak?

Adapun tujuan dari penelitian ini yang dapat dibagi menjadi 2 yaitu, tujuan umum dan tujuan khusus. Tujuan umum dari penelitian ini adalah:

Untuk memenuhi tugas sebagai persyaratan meraih gelar Sarjana Hukum pada Fakultas Hukum Universitas Warmadewa

Sebagai salah satu sarana penerapan ilmu hukum yang diperoleh selama perkuliahan yang terjadi dalam masyarakat.

Sebagai konstribusi pemikiran yang berguna bagi semua pihak yang terkait dengan permasalahan yang di bahas dan dapat menambah pengetahuan Mahasiswa Fakultas Hukum Universitas Warmadewa

Tujuan khusus dari penelitian ini adalah:

Untuk mengetahui kekuatan hukum verstek

Untuk mengetahui penjatuhan putusan verstek terhadap perkara cerai talak.

\section{Metode}

Metode penelitian
dilakukan oleh penulis manapun enting
penelitian normative maupun empiris,
dilakukannya penelitian hukum untuk
mengetahui bagaimana kita bisa menyelesaikan


kasus tertentu agar sesuai dengan prosedur yang tepat dan tidak melanggar aturan yang ada sehingga dapat meyelesaikan kasus yang ingin diselesaikan.

Metode penelitian hukum merupakan suatu kegiatan ilmiah untuk mengumpulkan, mengklarifikasi, menganalisis, dan menginterprestasif akta serta hubungan di lapangan hukum yang relavan bagi kehidupan hukum dalam rangka menjawab masalah yang teliti secara benar. Metode yang digunakan dalam pembuatan jurnal ini adalah metode normative. Metode normative adalah dimana penulis mengumpulkan bahan yang di dapatkan melalui pendekatan perundang-undangan, pendekatan konseptual, melakukan perbandingan hukum, serta didasari dan didukung bahan hukum primer, sekunder dan tersier. Penelitian hukum normative yaitu merupakan penelitian hukum yang mengkaji hukum tertulis dari berbagai aspek, tetapi tidak mengkaji aspek terapantau implementasinya (Sunggono, 2006).

Dalam hukum islam juga memiliki karakteristik tentang penelitian hukum normative yaitu:

Sumber bahan hukumnya yang terdiri dari bahan hukum primer, bahan hukum sekunder, dan bahan hukum tersier.

Penelitian hukum normative sepenuhnya menggunakan bahan hukum sekunder.

Penyusunan kerangka teoritis yang bersifat tenatif dapat ditinggalkan namun penyusunan konseptualnya mutlak diperlukan.

Dalam penelitian hukum normative tidak diperlukan hipotesis, kalaupun ada hanya hipotesis kerja.

Konsekuensi dari penggunaan bahan hukum sekunder maka penelitan hukum islam normative tidak diperlukan sampling karena data skunder memiliki bobot tersendiri yang tidak bisa digantikan dengan jenis lainnya (Misno, 2016).

Pada bahan hukum primer meliputi KUHPerdata, Undang-undang nomor 1 tahun 1974 tentang perkawinan, Undang-undang kekuasaan kehakiman nomor 48 tahun 2009, HIR dan RBg dan putusan nomor 0009/ Pdt.G/2018/PA.Bdg. Pada bahan hukum sekunder yaitu bahan-bahan hukum yang diperoleh dari pengkajian kepustakaan seperti buku-buku, jurnal penelitian ahli hukum, ensiklopedia yang berkaitan dengan hukum perdata serta karya ilmiah para sarjana yang berkaitan dengan masalah yang di bahas.

Penulis melakukan pengumpulan bahan hukum dengan cara studi pustaka dan studi kasus, dengan cara membaca dan mencatat informasi serta penjelasan yang di peroleh dari perundang-undangan, peraturan pemerintah yang didapatkan dari sumber hukum tersebut yang dapat dikaji lebih lanjut berhubung dengan masalah ini.

\section{Hasil Penelitian dan Pembahasan}

\section{Kekuatan Hukum Verstek Dalam Pemeriksaan Cerai Talak}

Perceraian pada umumnya adalah pisahnya suatu hubungan antara suami istri yang sudah terikat suatu hubungan pernikahan yang sah, dimana terjadinya suatu perceraian disebabkan oleh masalah-masalah serius yang dialami oleh suatu rumah tangga. Pasal 39 UU Perkawinan mengatur bahwa perceraian hanya dapat dilakukan di depan Sidang Pengadilan setelah Pengadilan yang bersangkutan berusaha dan tidak berhasil mendamaikan kedua belah pihak. Selain itu seorang suami harus memiliki alasan yang dapat diterima dan masuk akal mengapa suami meceraikan istrinya, adapun alasan yang dapat diterima oleh pihak pengadilan:

Salah satu pihak berbuat zina atau ,menjadi pemabuk, pemadat, penjudi dan lainnya sebagaimana yang susah dirubah

Salah satu pihak meninggalkan pihak lain selama 2 tahun berturut-turut tanpa izin pihak lain dan tanpa alasan yang sah

Salah satu pihak mendapat hukuman penjara 5 tahun atau hukuman yang lebih berat setelah perkawinan berlangsung

Salah satu pihak melakukan kekejaman atau penganiayaan berat yang membahayakan salah satu pihak

Salah satu pihak mengidap penyakit cacat badan dan penyakit dan tidak bisa menjalankan kewajibannya sebagai suami atau istri

Di rumah tangga selalu terjadi perselisihan yang terus menerus dan sudah tidak dapat hidup rukun kembali

Mengenai perceraian yang sudah biasa terjadi di kalangan masyarakat awam yang tak luput dari masalah-masalah yang timbul hingga menyebabkan perceraian, dimana perkara perceraian biasanya diselesaikan di pengadilan negeri yang ada di setiap daerah namun disini penulis membahas tentang perceraian yang ada 
di pengadilan agama yang lebih di khususkan hanya untuk umat muslim dan berdasarkan studi kasus di pengadilan agama badung dimana perkara perceraiannya tidak didatangi pihak termohon atau pihak istri yang sudah dipanggil secara sah oleh panitera pengganti yang diutus oleh ketua pengadilan dan majelis hakim. Dalam suatu persidangan ada kemungkinannya pada hari sidang yang telah ditentukan termohon tidak datang dan tidak pula mengirimkan wakilnya menghadap dipersidangan, sekalipun telah dipanggil secara patut. Jika termohon tidak hadir setelah dipanggil secara patut maka gugatan dapat dikabulkan dengan putusan tidak hadirnya pihak termohon atau verstek, kecuali pihak termohon itu melawan hak atau tidak beralasan (Sutantio \& Oeripkartawinata, 1986).

Dalam persidangan tersebut pihak termohon terus menerus tidak datang ke pengadilan meski sudah dipanggil secara resmi oleh panitera pengganti dan pihak termohon pun juga tidak mengirimkan walinya untuk mewakilkannya, karena hal tersebut pihak pemohon meminta untuk menjatuhkan putusan verstek kepada majelis hakim pengadilan agama badung dan mentalak satu pihak termohon sesuai dengan dalil-dalil yang pihak pemohon bawa kepengadilan, majelis hakim tidak dapat langsung memutus perkara tersebut dan majelis hakim berhak mengundur dan memanggil kembali pihak termohon.

\section{Penjatuhan Putusan Verstek Terhadap Perkara Cerai Talak}

Talak merupakan hak laki-laki sebagai seorang suami. Oleh karena itu ia berhak mentalak isterinya secara langsung atau mewakilkannya kepada orang lain. Jika seorang suami menyerahkan urusan isterinya kepada orang lain selain isterinya, maka hal itu tetap sah dan hukum yang berlaku padanya adalah hukum jika ia menyerahkan urusannya itu kepada isterinya (Ayyub, 2001).

Setelah dilakukannya pemanggilan lagi terhadap pihak termohon oleh panitera pengganti dan tetap tidak hadir dalam sidang yang sudah di tentukan maka majelis hakim pun memutus perkara tersebut dengan putusan verstek dan mentalak satu pihak termohon sesuai dengan permohonan pihak pemohon serta membuktikan kembali dalil-dalil dan dasar pihak pemohon mentalak satu pihak termohon. Majelis hakimpun mengabulkan permohonan pemohon yang mentalak satu termohon dengan putusan verstek beserta bukti-bukti yang diberikan di pengadilan sesuai dengan studi kasus No. 0009/Pdt.G/2018/PA.bdg yang penulis bahas.

Dalam studi kasus ini pemohon yang membawa perkara dan memohon putusan di kabulkan sudah terlaksana dan sudah mentalak satu pihak termohon meski tidak pernah hadir dalam persidangan dan sudah dipanggil secara resmi.

\section{Simpulan}

Berdasarkan hasil penjelasan pembahasan permasalahan diatas maka dapat ditarik kesimpulan yaitu:

Kekuatan hukum verstek dalam pemeriksaan perkara cerai talak dengan dijatuhkannya putusan ini permohonan pemohon sudah dikabulkan dengan putusan nomor 0009/Pdt.G/2018/PA.Bdg yang memutus bahwa pihak pemohon meceraikan pihak termohon dengan talak satu dimana dengan dalil-dalil pemohon yang sudah bosan dan tidak tahan karena pihak termohon selalu menuduh pemohon berselingkuh. Beban biaya perkara tetap dijatuhkan atau dibebankan kepada pemohon karena sesuai dengan undang-undag Nomor 7 tahun 1988 sebagaimana telah diubah dengan undang-undng Nomor 3 tahun 2008 dan perubahan kedua dengan undang-undang Nomor 59 tahun 2008, yang berbunyi biaya perkara harus dibebankan kepada penggugat atau pemohon.

Putusan hakim dalam memutus perkara cerai talak dengan verstek ini dikabulkan karena pemohon sudah cukup banyak memberikan dalil-dalil yang memperkuat hakim memutus perkara ini, dengan dasar hukum verstek pasal 125 HIR dan 149 RBG bahwa dengan ketidakhadiran pihak termohon berarti pihak termohon sudah melepas hak jawabnya dan dianggap mengakui segala dalil-dalil yang diajukan oleh pihak pemohon kepada majelis hakim dan pihak termohon juga tidak mengajukan perlawanan atau verzet untuk membantah atau memberi tangkisan terhadap putusan verstek tersebut.

\section{Daftar Pustaka}

Ayyub, S. H. (2001). Fikih Kelarga. Jakarta: Pustaka Al-Kautsar.

Malik, R. A. (2012). Ketidakhadiran Pemohon Dalampelaksanaan Ikrar Talak (Studi Kasus Di Pengadilan Agama Ambarawa). Jurusan Syari'ah Program Studi Ahwal Al-Syakhsyiyyah Sekolah 
Tinggi Agama Islam Negeri (Stain)

Salatiga. Retrieved from http://erepository.perpus.iainsalatiga.ac.id/310

2/1/R. Abdul Malik.pdf

Misno, A. (2016). Metode Penelitian Hukum Islam. Bogor: Pustaka AMMA.

Prodjohamidjojo, M. (2002). Hukum Perkawinan Indonesia. Yogyakarta: Graha Indonesia.

Putri, D. K., Bachtiar, M., \& Dasrol. (2016). Implementasi Mediasi Pada Perkara Cerai Talak Dalam Hal Ketidakhadiran Tergugat Di Pengadilan Agama Pekanbaru. JOM Fakultas Hukum, 3(2). Retrieved from https://media.neliti.com/ media/publications/183378-IDnone.pdf

Sunggono, B. (2006). Metode Penelitian Hukum. Jakarta: Rajawali Pers.

Sutantio, R., \& Oeripkartawinata, I. (1986). Hukum Acara Perdata Dalam Teori dan Praktek, Cetakan V. Bandung: Mandar Maju. 